\title{
Early host response in the mammary gland after experimental Streptococcus uberis challenge in heifers
}

\author{
Astrid de Greeff, ${ }^{\star 1}$ Ruth Zadoks, †‡ Lisette Ruuls, ${ }^{*}$ Mathilda Toussaint,§ Thi Kim Anh Nguyen,§ \\ Alison Downing,\# Johanna Rebel, ${ }^{*}$ Norbert Stockhofe-Zurwieden, ${ }^{*}$ and Hilde Smith* $† \ddagger$ \\ ${ }^{*}$ Central Veterinary Institute of Wageningen University and Research Centre, Edelhertweg 15, 8219 PH Lelystad, the Netherlands \\ †Moredun Research Institute, Pentlands Science Park, Bush Loan, Penicuik EH26 OPZ, United Kingdom \\ $\ddagger$ College of Medical, Veterinary and Life Sciences, University of Glasgow, Glasgow G61 1QH, United Kingdom \\ $\S$ Department of Pathobiology, Faculty of Veterinary Medicine, Utrecht University, Yalelaan 1, NL-3508-TD Utrecht, the Netherlands \\ \#ARK Genomics, Roslin Institute, Midlothian EH25 9PS, United Kingdom
}

\section{ABSTRACT}

Streptococcus uberis is a highly prevalent causative agent of bovine mastitis, which leads to large economic losses in the dairy industry. The aim of this study was to examine the host response during acute inflammation after experimental challenge with capsulated Strep. uberis. Gene expression in response to Strep. uberis was compared between infected and control quarters in 3 animals. All quarters $(\mathrm{n}=16)$ were sampled at 16 different locations. Microarray data showed that 239 genes were differentially expressed between infected and control quarters. No differences in gene expression were observed between the different locations. Microarray data were confirmed for several genes using quantitative PCR analysis. Genes differentially expressed due to early Strep. uberis mastitis represented several stages of the process of infection: (1) pathogen recognition; (2) chemoattraction of neutrophils; (3) tissue repair mechanisms; and (4) bactericidal activity. Three different pathogen recognition genes were induced: ficolins, lipopolysaccharide binding protein, and toll-like receptor 2. Calgranulins were found to be the most strongly upregulated genes during early inflammation. By histology and immunohistochemistry, we demonstrated that changes in gene expression in response to Strep. uberis were induced both in infiltrating somatic milk cells and in mammary epithelial cells, demonstrating that the latter cell type plays a role in milk production as well as immune responsiveness. Given the rapid development of inflammation or mastitis after infection, early diagnosis of (Strep. uberis) mastitis is required for prevention of disease and spread of the pathogen. Insight into host responses could help to design immunomodulatory therapies to dampen inflammation

Received October 29, 2012.

Accepted February 25, 2013.

${ }^{1}$ Corresponding author: astrid.degreeff@wur.nl after (early) diagnosis of Strep. uberis mastitis. Future research should focus on development of these early diagnostics and immunomodulatory components for mastitis treatment.

Key words: mastitis, Streptococcus uberis, host response, microarray

\section{INTRODUCTION}

Mastitis is an inflammation of the mammary gland that is usually caused by bacterial infection. Worldwide, Streptococcus uberis is a common causative agent for bovine mastitis (Bradley et al., 2007; Compton et al., 2007; Olde Riekerink et al., 2008). Streptococcus uberis is considered an environmental pathogen; it has been recovered from soil, bedding material, and feces, as well as from several areas on the cow such as skin and udder (Smith and Hogan, 1993; Zadoks et al., 2011). In addition to clinical cases of mastitis, chronic subclinical intramammary infections with Strep. uberis occur frequently on dairy farms (Jayarao et al., 1999; Zadoks et al., 2003; Bradley et al., 2007). Subclinical infections often result in persistence of Strep. uberis, which may lead to spread of the disease (Zadoks et al., 2001, 2003). In addition, subclinical mastitis can flare up under certain conditions, causing clinical mastitis (Jayarao et al., 1999; Zadoks et al., 2003; Bradley et al., 2007). A recent study in the Netherlands showed that, despite preventive measures, prevalence of Strep. uberis infections has not decreased compared with $30 \mathrm{yr}$ ago (Sampimon et al., 2009). Farmers' knowledge and perception play a crucial role in efforts to reduce the occurrence of mastitis based on current scientific knowledge of the disease (Jansen et al., 2010). In addition, enhanced understanding of the biology of mastitis may contribute to development of new control measures, such as immunomodulatory components to suppress (part of) the overwhelming inflammatory response. Compared with the host response to Staphylococcus aureus and Escherichia coli mastitis, the response to 
Strep. uberis mastitis is relatively poorly understood (Schukken et al., 2011; Wellnitz and Bruckmaier, 2012).

The physiological host response to infection is initiated by pathogen recognition that subsequently triggers the acute phase response, which is central to innate immunity of the host. The aim of this study was to examine the host response during acute inflammation in heifers after experimental challenge with Strep. uberis using microarrays and immunohistochemistry. In a previous study, the immune response to challenge with a noncapsular Strep. uberis wild-type strain was analyzed in heifers (Swanson et al., 2009). The strain had been isolated from a case of clinical mastitis in the field, and unencapsulated mutants of Strep. uberis are known to have the have the ability to cause clinical mastitis after experimental challenge (Field et al., 2003; Swanson et al., 2009). Carriage of the hasA gene, which is required for capsule production by Strep. uberis, has, however, been linked to clinical mastitis, whereas absence of hasA has been linked to subclinical infection (Pullinger et al., 2006; Tomita et al., 2008; Swanson et al., 2009). Thus, further study into the in vivo host response to encapsulated Strep. uberis may provide further insight into the pathogenesis of clinical Strep. uberis mastitis.

We used 2 encapsulated Strep. uberis isolates, reference strain O140J (Hill, 1988) and a Dutch field isolate (41-241), which was part of an outbreak of clinical and subclinical mastitis affecting multiple cows (Zadoks et al., 2003). The isolates belonged to sequence types 1 and 385 , respectively, and are part of 2 global clonal complexes (GCC5 and GCC143, respectively) that are associated with a large number of mastitis cases in numerous countries (Zadoks et al., 2011). To evaluate the primary response to Strep. uberis challenge, primiparous heifers were used for infection.

\section{MATERIALS AND METHODS}

\section{Bacterial Strains and Growth Conditions}

Streptococcus uberis strains O140J (Leigh et al., 1990) and 41-241 (Zadoks et al., 2001) were grown on Columbia agar blood base plates (Oxoid Ltd., London, UK) containing 6\% (vol/vol) horse blood and $0.1 \%$ (vol/vol) esculin. To prepare the inoculum, cultures were grown in Todd-Hewitt broth (Oxoid) for $16 \mathrm{~h}$ at $37^{\circ} \mathrm{C}$. Subsequently, cultures were diluted 1:10 in ToddHewitt broth and grown to exponential phase. Cells were washed once with PBS, and the inoculum was prepared based on the optical density of the culture. The final concentration of the inoculum was determined by plating serial dilutions on Columbia agar blood base plates containing $6 \%(\mathrm{vol} / \mathrm{vol})$ horse blood and $0.1 \%$ (vol/vol) esculin.

\section{Experimental Infection}

Four Holstein-Friesian primiparous heifers in early lactation with no history of mastitis (based on clinical signs) were inoculated with Strep. uberis. Before inclusion in the experiment, SCC values in the quarter milk of all animals were determined to be $<1.5 \times 10^{5}$ cells $/ \mathrm{mL}$ using methodology described later, and milk was checked bacteriologically by plating $100 \mu \mathrm{L}$ on Columbia agar blood base plates containing $6 \%$ (vol/vol) horse blood and $0.1 \%$ (vol/vol) esculin for absence of Strep. uberis colonies under UV light. Before inoculation via the teat canal, teats were disinfected with iodine. Two diagonally opposed quarters of each animal were challenged intramammarily with Strep. uberis, and the remaining 2 quarters were mock challenged with $\mathrm{PBS}$ $\left(0.1 M \mathrm{NaCl}, 33 \mathrm{mM} \mathrm{Na} 2 \mathrm{PO}_{4}, 17 \mathrm{~m} M \mathrm{NaH}_{2} \mathrm{PO}_{4} \cdot 2 \mathrm{H}_{2} \mathrm{O}\right.$; $\mathrm{pH}$ 7.4) and served as within-cow control quarters. Two animals were challenged with Strep. uberis strain O140J (500 cfu). Because the virulence of strain 41-241 was unknown, one animal was challenged with a dose of $500 \mathrm{cfu}$ and the other with 5,000 cfu. Cows were inoculated after the $1600 \mathrm{~h}$ milking with a short blunt-ended needle, and the udder was massaged to distribute the inoculum. After inoculation, milk and blood samples were taken twice daily at 1000 and $1600 \mathrm{~h}$ and kept at $-20^{\circ} \mathrm{C}$ until use. Milk was analyzed bacteriologically as described above, and SCC of milk were determined. Rectal temperature, milking volume per quarter, hematology indices, and general health of animals were monitored throughout the experiment.

The heifers were euthanized after 2 increased SCC $\left(>10^{6} \mathrm{cfu} / \mathrm{mL}\right)$ at 2 subsequent milkings. Animals that did not display increased SCC were euthanized at the end of the experiment ( $4 \mathrm{~d}$ postchallenge). The udder was removed and tissue samples were collected from various locations of control and infected mammary quarters. Each quarter was sampled distally (teat cistern and gland cistern) and proximally (level 1 and level 2 at 4 locations: medio-cranial, medio-caudal, latero-cranial, and latero-caudal; Figure 1), immediately after the animals were euthanized. Samples from all 16 locations were snap-frozen in liquid nitrogen for RNA isolation and stored at $-70^{\circ} \mathrm{C}$. Samples from the same 16 locations were examined bacteriologically by swabbing samples with an inoculation loop and plating the contents on Columbia agar blood base plates containing $6 \%$ (vol/vol) horse blood and $0.1 \%$ (vol/vol) esculin and counting Strep. uberis colonies under UV light. Samples from the same 16 locations were fixed in formalin, embedded in paraffin, sectioned at 3 to $5 \mu \mathrm{m}$, and subsequently stained with hematoxylin and eosin (Merck, Darmstadt, Germany) for histological assessment or used for immunohistochemistry as described 


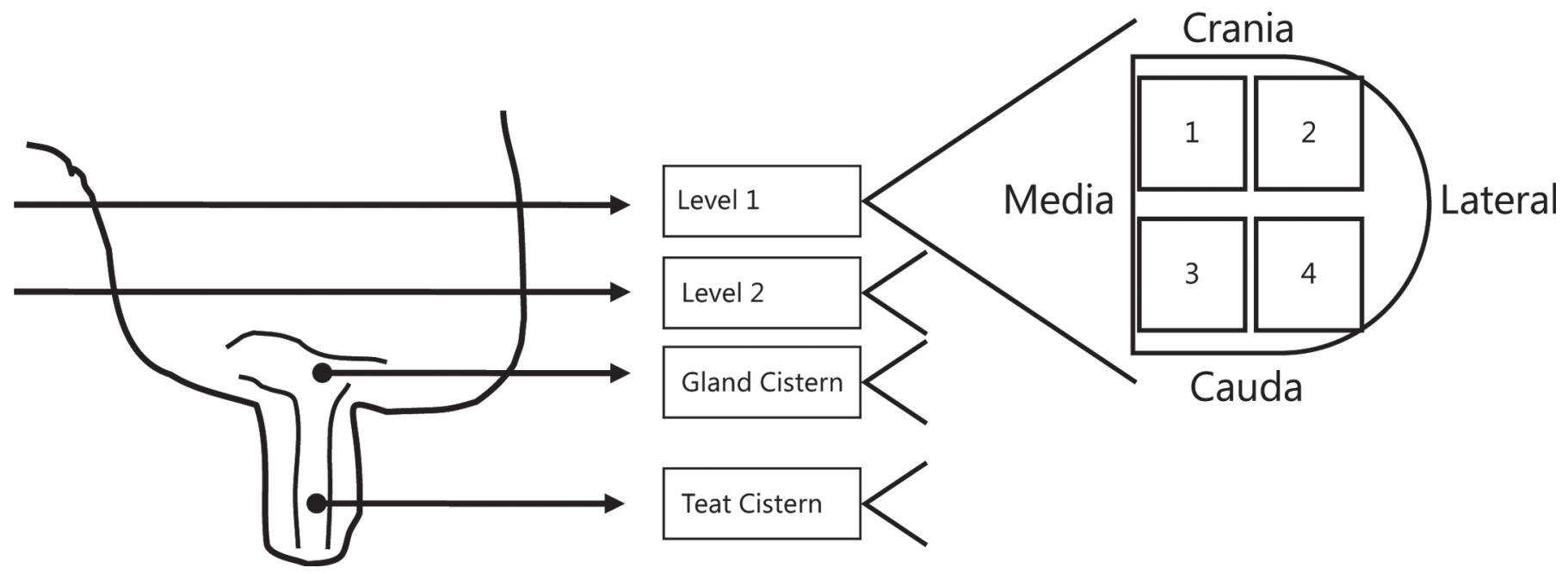

Figure 1. Locations that were sampled in udder quarters; numbers indicate locations sampled at each level.

below. Sections stained with hematoxylin and eosin were examined for signs of inflammation. All animal experiments were approved by the ethical committee of the Central Veterinary Institute of Wageningen UR (Lelystad, the Netherlands) in accordance with the Dutch law on animal experiments.

\section{SCC}

Milk cells were fixed in $2 \%$ formaldehyde containing $2 \mu \mathrm{g} / \mathrm{mL}$ eosin solution for $50 \mathrm{~min}$ at $55^{\circ} \mathrm{C}$. After fixation, the milk was cooled to room temperature. Fixed cells were diluted 100-fold in Tolle electrolyte solution [2\% Triton-X100, $12.5 \%$ ethanol, $1 \%$ formalin (37\%), and $84.5 \% \mathrm{NaCl}(0.9 \%)$ ] and incubated for $15 \mathrm{~min}$ at $80^{\circ} \mathrm{C}$. After incubation, samples were cooled to room temperature. Subsequently, SCC in milk were determined for each quarter using a Coulter Counter (Beckman Coulter, Fullerton, CA).

\section{Immunohistochemistry}

Tissue sections on silan-coated slides were incubated for 30 min in $0.05 \%$ trypsin in $\mathrm{H}_{2} \mathrm{O}$, followed by washing 3 times in PBS, pH 7.4. Slides were incubated in $0.3 \% \mathrm{H}_{2} \mathrm{O}_{2}$ in methanol for $30 \mathrm{~min}$ at room temperature (RT; 18 to $\left.20^{\circ} \mathrm{C}\right)$. After washing 3 times in PBS with 0.1\% Tween-20 and $0.025 \%$ Triton X-100 (PTTX), slides were incubated with $10 \%$ goat serum in PBS with $1 \%$ BSA and $0.025 \%$ Triton X-100 (PBTX) for $30 \mathrm{~min}$ at RT, followed by incubation with primary antibody against human tissue inhibitor of metalloproteinase 1 (TIMP-1; Abcam, Cambridge, UK), human superoxide dismutase 2 (SOD-2; Abcam), and bovine serum amyloid A (SAA; Tridelta Development Ltd., Greystones, Co. Wicklow, Ireland) diluted 1:25, 1:250, and 1:100 respectively, in PBTX, and incubated overnight at $4^{\circ} \mathrm{C}$. Antibodies against human SOD-2 were described to show cross-reactivity with bovine SOD-2 by the manufacturer, and antibodies against human TIMP-1 were shown to cross-react with bovine TIMP-1 in this study. Slides were then washed 3 times in PTTX and incubated with goat anti-rabbit biotin (Dako, Glostrup, Denmark) in PBTX for 30 min at RT. Slides were washed 3 times in PTTX and incubated with streptavidin-horseradish peroxidase (Dako) in PBTX for 30 min at RT. Sections were washed in PBS and stained with 3,3'-diaminobenzidine substrate (SigmaAldrich, St. Louis, MO) for 5 min. After washing for $10 \mathrm{~min}$ in water, slides were counterstained with hematoxylin (Merck) for $3 \mathrm{~s}$. Slides were washed for $10 \mathrm{~min}$ under running tap water, dehydrated, and covered with Eukitt mounting medium (Kindler GmBH, Freiburg, Germany). Slides were inspected qualitatively using a light microscope and representative pictures were taken.

\section{Serum Amyloid A Assay}

Levels of SAA in milk and plasma samples were measured as described previously by Jacobsen et al. (2005) using a commercially available sandwich ELISA kit (Tridelta Development Ltd.). Both milk and plasma samples were appropriately diluted (1:50 to $1: 5,000)$. Optical density values were read on an automatic plate reader (Microplate Reader, Bio-Rad, Hercules, CA) at $450 \mathrm{~nm}$ with reference at $595 \mathrm{~nm}$, and concentrations were determined based on a standard curve of diluted positive control provided with the ELISA kit. 


\section{RNA Isolation}

Udder tissue samples were ground in Trizol (Invitrogen, Carlsbad, CA) using a tissue homogenizer. Then, 0.2 vol of chloroform was added and the sample was extracted. The RNA in the aqueous phase was precipitated with isopropanol and the pellet was washed in $70 \%$ ethanol. The RNA pellet was dissolved in water and further purified using RNeasy column purification (Qiagen, Hilden, Germany). Quality and quantity of RNA was checked using Nanodrop (Thermo Fisher Scientific, Pittsburgh, PA) and BioAnalyzer (Agilent, Palo Alto, CA).

\section{Microarray Analysis}

Based on histology results, udder locations that showed clear signs of inflammation, such as neutrophil influx, interstitional inflammation, or purulent exudate, were selected for microarray analysis. From each animal, 2 samples were selected for microarray analysis: 1 sample from a proximal location (level 1 or level 2) and 1 sample from a distal location (mammary gland cistern or teat cistern; Supplementary Table 2; available online: http://www.journalofdairyscience.org/). For control quarters, samples taken at matching locations from 1 control quarter were pooled $(\mathrm{n}=2)$ per animal because no discernible differences were observed between different locations in the control quarters when inspected microscopically. On each microarray, RNA from a selected location of an inflamed quarter was compared with pooled RNA from locations of a control quarter. Twenty micrograms of total RNA was labeled using the Fairplay Microarray Labeling Kit (Stratagene, La Jolla, CA) according to the manufacturer's protocol with some modifications. Reverse transcription was performed for $60 \mathrm{~min}$ at $48^{\circ} \mathrm{C}$. Subsequently, cDNA was precipitated overnight at $-20^{\circ} \mathrm{C}$. Dyes containing $N$-hydroxysuccinimide (NHS) ester ( $\mathrm{Cy} 3 / \mathrm{Cy} 5$ ) were coupled to the cDNA, and the labeled cDNA was purified using QIAex DyeEx spin columns (Qiagen) according to the manufacturer's protocol. Hybridization to the ARK $20 \mathrm{~K}$ bovine cDNA library was performed using a hybridization station (Genomic Solutions, Ann Arbor, MI).

Microarrays were analyzed using BlueFuse (Bluegnome Limited, Cambridge, UK) and Genespring (Agilent, Santa Clara, CA). The experimental design had 4 sources (strata) of biological or technical variation; that is, between cows, between quarters (individual challenged quarters, pooled control quarters) within cows, between strains, and between dye-swapped slides, and was balanced. The first 2 strata were analyzed by separate regression analyses. Initially, the first 3 strata were analyzed by separate regression analyses. Because no significant differences in expression levels were found between strains, data from all challenged quarters was subsequently analyzed jointly as "infected" and compared with data from control quarters. The infected versus control effect was tested across cows. A small value $\left(256=2^{8}\right)$ was added to the intensities in both channels for all spots to account for spots that had no signal in one of the channels and shifted the data. The normalization and analysis methods followed the steps in the Limma package of the Bioconductor open source software (http://www.bioconductor.org/), with additional plotting from the Bioconductor Marray package, and with modification of the Limma models at both normalization and analysis stages. The normalization was a 2-step process of spatial and intensity-dependent bias correction. This is a compromise between highly local single-block row-column spatial correction and chip-wide row-column correction. The intensity-dependent bias was removed by block-Lowess. The analyses were performed on means of replicate spots $(n=2)$. The Limma eBayes correction was used to shrink the residual variances of genes toward their (approximate) median value. Genes were considered "significant" for a comparison if their Limma-estimated false detection rate (FDR) was $<5 \%$.

\section{Quantitative PCR Analysis}

Two hundred nanograms of RNA from the same udder locations that were analyzed in the microarray was used to synthesize cDNA in a reaction containing 25 $\mathrm{ng} / \mu \mathrm{L}$ random primers (Promega, Madison, WI), 10 $\mathrm{m} M$ deoxynucleotide triphosphates (Promega), $10 \mathrm{mM}$ dithiothreitol (Invitrogen), 40 U of RNAsin (Promega), and SuperScriptII Reverse Transcriptase (Invitrogen) according to manufacturers' instructions.

The cDNA was diluted 20 times for quantitative (q) PCR analysis. Primers were designed for 11 strongly regulated genes, as identified by microarray, using PrimerExpress software (Applied Biosystems, Foster City, CA; see Table 1). Each reaction contained 12.5 pmol of forward primer, $12.5 \mathrm{pmol}$ of reverse primer and POWR SYBR Green PCR Master Mix (Applied Biosystems), according to the manufacturer's instructions. The qPCR was performed using an ABI7500 sequencer (Applied Biosystems), and GeNorm (Sequenom, San Diego, CA) was used to determine the most stably expressed reference gene. Out of 5 potential reference genes $(16 S$, actB, sdhA, eif2b2, ppiA), sdhA was the most stably expressed (data not shown). The amount of $s d h A$ was measured to control for variation in the RNA yield and reverse transcription reaction conditions. In each run, a standard curve was incorporated consisting of a vector 
Table 1. Primer sequences

\begin{tabular}{lll}
\hline Gene name & Forward primer & Reverse primer \\
\hline CD-244 & TGAGCAAAAAGAGGATGGTTACC & ACCTCGGACTCTCCAAGATTCTC \\
Indoleamine 2,3,-dioxygenase & CGTGTGGAAGTTGAGAAGTTAGCA & CGCCTTGACCCCACACATAC \\
Dendritic cell derived IFN- $\gamma$ induced protein & AGGAGTGGCAAAATCAAGCAA & GGCCACGGTGCTTCCA \\
Very large inducible GTP-ase & CATCACCCCAGACACATCCA & CCAGGCATCAGGAATTCACTT \\
Acyl-CoA synthetase long-chain family member 6 & AACCTCCATGTGAAGTTCAAGGA & GGTCACGTGCTTTTCATTTTCAG \\
J domain containing protein/DNAJ & AAAGGACATTTTGACTAATGAAGCAA & ACTGCTGGAATGACATTGATATCTG \\
Stearyl CoA desaturase & CGATGTCAAAGTTATATGGGTGGTT & CCAGGGTCACATAGCAAGTCAGT \\
Calgranulin A & CCCTGATTGACGTCTACCACAA & CCCTATAGACGGCGTGGTAAT \\
Complement factor B & TGCACTGAGGGATCGATTCA & GGGAGTAGCTCTTGCATCTGTTG \\
Lipopolysaccharide binding protein & AATTTATTGAGGACCCACCAAGTG & CAGAATAGACCATCCTCACCCATT \\
Tissue inhibitor of metalloproteinase 1 & ATGCTGCTGGTTGTGAGGAAT & TGTCGCTCTGCAGTTTGCA \\
Superoxide dismutase 2 & CATCAACGCGCAGATCATG & CTCGGCGACGTTGAGGTT \\
Serum/glucocorticoid regulated kinase & TGCAAGGAGAACATTGAACACAA & CACCTCAGGCGCCAGATACT \\
Serum amyloid A & CCAGGCTGCCAACGAATG & GGGACTCACAGCCCCATCT \\
\hline
\end{tabular}

containing the PCR product of the target gene of that reaction. The standard curve consisted of seven 10-fold dilutions of the control vector. In this way, both the target gene of $\mathrm{qPCR}$ analysis as well as the external control gene sdhA could be related to a standard line. The efficiency of the PCR reaction was 80 to $100 \%$ for all reactions. For each reaction, negative water controls were included. Analysis was performed using the ABI7500 software (Applied Biosystems). Two-way ANOVA was used to determine whether significant differences were present between sample locations.

\section{RESULTS}

\section{Experimental Infection}

Results of experimental challenges are summarized in Table 2 (clinical, cytological, and bacteriological response) and Figure 2 (milk yield and SAA response). Of 4 heifers, 1 animal (no. 1) developed systemic signs of illness (fever) without localized signs of mastitis, 1 animal (no. 3) developed systemic (fever) and local signs, and 1 animal (no. 4) developed local signs only. These 3 animals were euthanized for tissue sample collection after the second elevated SCC at time points as specified in Table 2. The SCC of these 3 animals uniformly increased in both infected quarters simultaneously (Table 2 ). Uninfected quarters also displayed a slight increase in SCC, but the difference between infected and control quarters was obvious. Timing of increased SCC differed between animals; the animal infected with the highest dose showed symptoms first, and the other animals followed within $24 \mathrm{~h}$. The fourth animal (no. 2) showed only mild elevation of SCC without clinical signs and was excluded from microarray analysis. Bacteriological examination showed that 7 of 8 challenged quarters were positive for Strep. uberis irrespective of the isolate used, whereas control quarters were negative for Strep. uberis (data not shown). Postmortem observation on the animals culled at the onset of the acute phase of intramammary infection showed mild to moderate edema, some intracisternal clots, and enlargement of local lymph nodes. Histology showed that all infected quarters showed signs of mastitis, such as interstitial inflammation and catarrhal-purulent changes, ranging from mild to severe, including one quarter of the animal that did not meet our criteria. Tissue sections stained with hematoxylin and eosin microscopically showed clear signs of catarrhal purulent mastitis with neutrophil influx in the 3 animals that did meet our criteria (Figure 3).

\section{Gene Expression in Strep. uberis-Infected Mammary Tissue}

To study the host response during acute infection in more detail, gene expression in 2 different locations - distal (teat cistern and gland cistern) versus proximal (level 1 and level 2) - of an infected quarter was compared with that of control quarters. Similar changes in host gene expression were induced by the 2 Strep. uberis isolates, and no statistically significant discernible gene expression patterns were found between samples obtained from different locations (distal or proximal). Therefore, infected tissue was compared with control tissue. A comparison between gene expression levels of infected tissue and control tissue resulted in 239 genes that were significantly regulated during mastitis (Supplementary Table S1; available online: http://www.journalofdairyscience.org/). Relevant upor downregulated genes in infected udder tissue with an FDR of $<5 \%$ are listed in Table 3 . The strongest regulated genes were calgranulins, which are strong chemoattractants, but genes involved in the complement system (complement factor B, C2), genes with bactericidal capacity [indoleamine-2,3 dioxygenase 
Table 2. Clinical outcome of intramammary Streptococcus uberis infection

$\frac{\tilde{O}}{\omega}$

\begin{tabular}{|c|c|c|c|c|c|c|c|c|c|c|c|}
\hline \multirow[b]{2}{*}{ Cow } & \multicolumn{2}{|c|}{ Strep. uberis } & \multirow[b]{2}{*}{ Quarter $^{1}$} & \multicolumn{2}{|c|}{$\mathrm{SCC}\left(10^{6}\right.$ cells $\left./ \mathrm{mL}\right)$} & \multirow[b]{2}{*}{$\begin{array}{c}\text { Lifespan } \\
\text { postinoculation (h) }\end{array}$} & \multirow[b]{2}{*}{$\begin{array}{c}\text { Maximum } \\
\text { temperature }{ }^{2}\left({ }^{\circ} \mathrm{C}\right)\end{array}$} & \multirow{2}{*}{$\begin{array}{l}\text { No. of } \\
\text { infected } \\
\text { quarters }\end{array}$} & \multirow[b]{2}{*}{$\begin{array}{l}\text { Bacteriology } \\
\text { score }^{3}\end{array}$} & \multirow[b]{2}{*}{$\begin{array}{c}\text { Clots } \\
\text { in milk }\end{array}$} & \multirow[b]{2}{*}{$\begin{array}{l}\text { Udder } \\
\text { consistency }^{5}\end{array}$} \\
\hline & Strain & $\begin{array}{l}\text { Dose } \\
\text { (cfu) }\end{array}$ & & Preinfection & Maximum & & & & & & \\
\hline \multirow[t]{4}{*}{1} & O140J & $5 \times 10^{2}$ & $\mathrm{RF}$ & 0.08 & 17 & 50 & 40.2 & 2 & 3 & & \\
\hline & & & LF & 0.05 & 0.2 & & & & & & \\
\hline & & & $\mathrm{RH}$ & 0.03 & 1.1 & & & & & & \\
\hline & & & LH & 0.03 & 30 & & & & 3 & & \\
\hline \multirow[t]{4}{*}{$2^{6}$} & O140J & $5 \times 10^{2}$ & $\mathrm{RF}$ & 0.06 & 1 & 80 & 38.6 & 1 & 1 & & \\
\hline & & & LF & 0.1 & 0.4 & & & & & & \\
\hline & & & RH & 0.04 & 0.2 & & & & & & \\
\hline & & & LH & 0.1 & 0.6 & & & & & & \\
\hline \multirow[t]{4}{*}{3} & $41-241$ & $5 \times 10^{3}$ & $\mathrm{RF}$ & 0.06 & 9 & 45 & 40.8 & 2 & 3 & 2 & 1 \\
\hline & & & LF & 0.009 & 0.06 & & & & & & \\
\hline & & & RH & 0.1 & 0.1 & & & & & & \\
\hline & & & LH & 0.03 & 28 & & & & 3 & & 1 \\
\hline \multirow[t]{4}{*}{4} & $41-241$ & $5 \times 10^{2}$ & $\mathrm{RF}$ & 0.03 & 20 & 67 & 38.7 & 2 & 3 & 1 & 1 \\
\hline & & & LF & 0.02 & 0.1 & & & & & & \\
\hline & & & RH & 0.02 & 0.3 & & & & & & \\
\hline & & & LH & 0.05 & 7 & & & & 2 & & 1 \\
\hline
\end{tabular}

${ }^{1} \mathrm{RF}=$ right front quarter; $\mathrm{LF}=$ left front quarter; $\mathrm{RH}=$ right hind quarter; $\mathrm{LH}=$ left hind quarter.

${ }^{2}$ Temperature $\geq 39.5^{\circ} \mathrm{C}$ was considered fever.

${ }^{3}$ Where $0=$ bacteriology score negative; $1=<10^{3} \mathrm{cfu} / \mathrm{mL}$ of milk; $2=<10^{5} \mathrm{cfu} / \mathrm{mL}$ of milk; $3=>10^{5} \mathrm{cfu} / \mathrm{mL}$ of milk.

${ }^{4}$ Where $0=$ normal milk; $1=$ few clots; $2=$ numerous clots; $3=$ milk with pus; $4=$ milk with blood.

${ }^{5}$ Where $0=$ normal consistency; $1=$ mild changes; $2=$ moderate changes; $3=$ severe changes

${ }^{6}$ This animal did not meet the criteria of increased SCC in 2 subsequent milkings and was excluded for further analysis. 

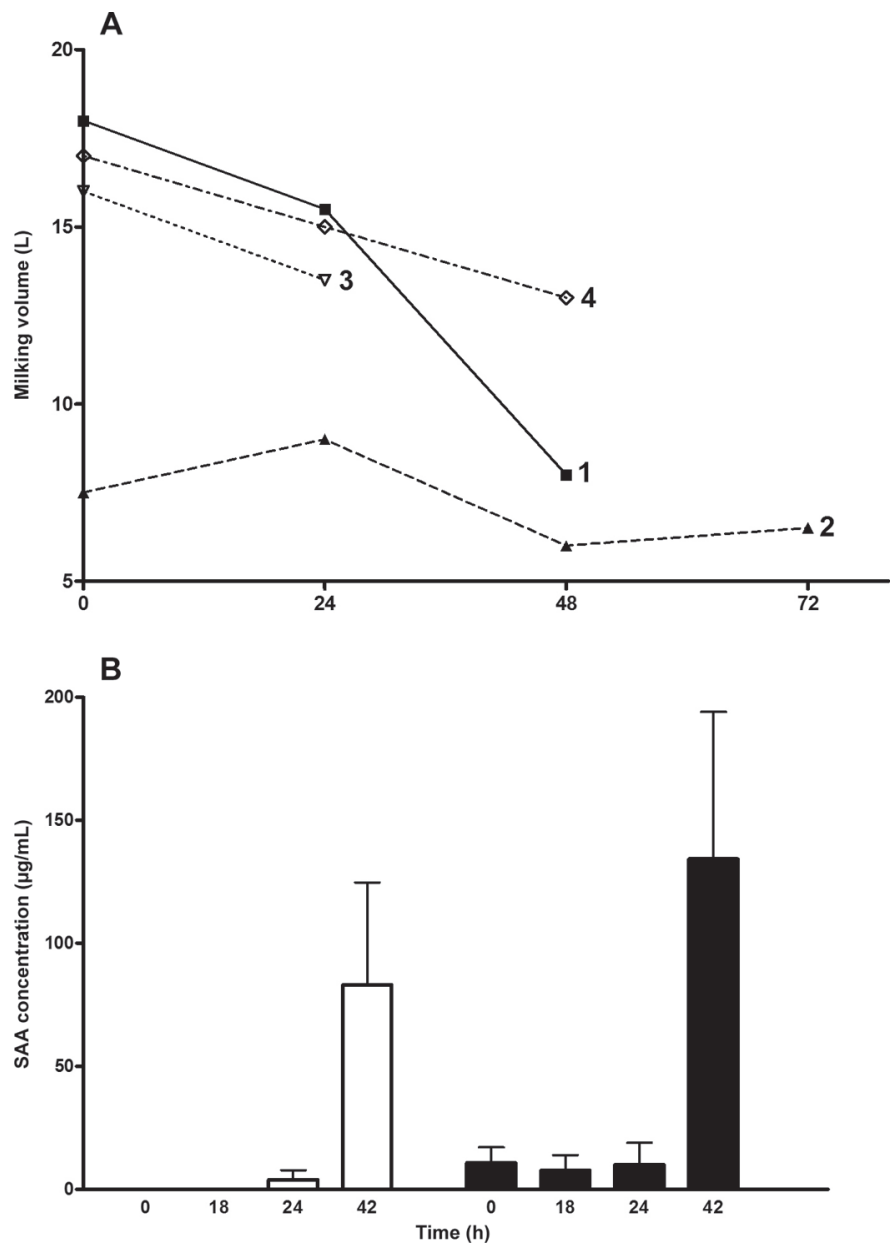

Figure 2. Milking volumes and serum amyloid A (SAA) concentrations in serum and milk of heifers challenged with Streptococcus uberis Each line in panel A represents the milking volume of one individual animal. Numbers correspond to animal numbers in Table 2. In panel $\mathrm{B}$, SAA concentrations in milk (white bars) and plasma (black bars) are average values of all animals alive at the moment of sampling. Because of culling of animals, the number of animals changed over time. Error bars indicate standard deviation.

(IDO), SOD], and genes protecting the udder tissue (TIMP-1) were also regulated.

\section{Confirmation of Array Data Using qPCR}

Gene expression of 10 genes differentially expressed between infected and control udder quarters (2 downregulated and 8 upregulated genes) was confirmed using qPCR analysis on udder samples from individual animals. Based on the increased protein levels of SAA found in serum and milk, gene expression of SAA was included as well. From infected and control quarters, the same samples from the distal udder (gland or teat cistern) and proximal udder regions (level 1 and level 2 ) that were used for microarray analysis were analyzed using qPCR (Supplementary Table S2; available online:
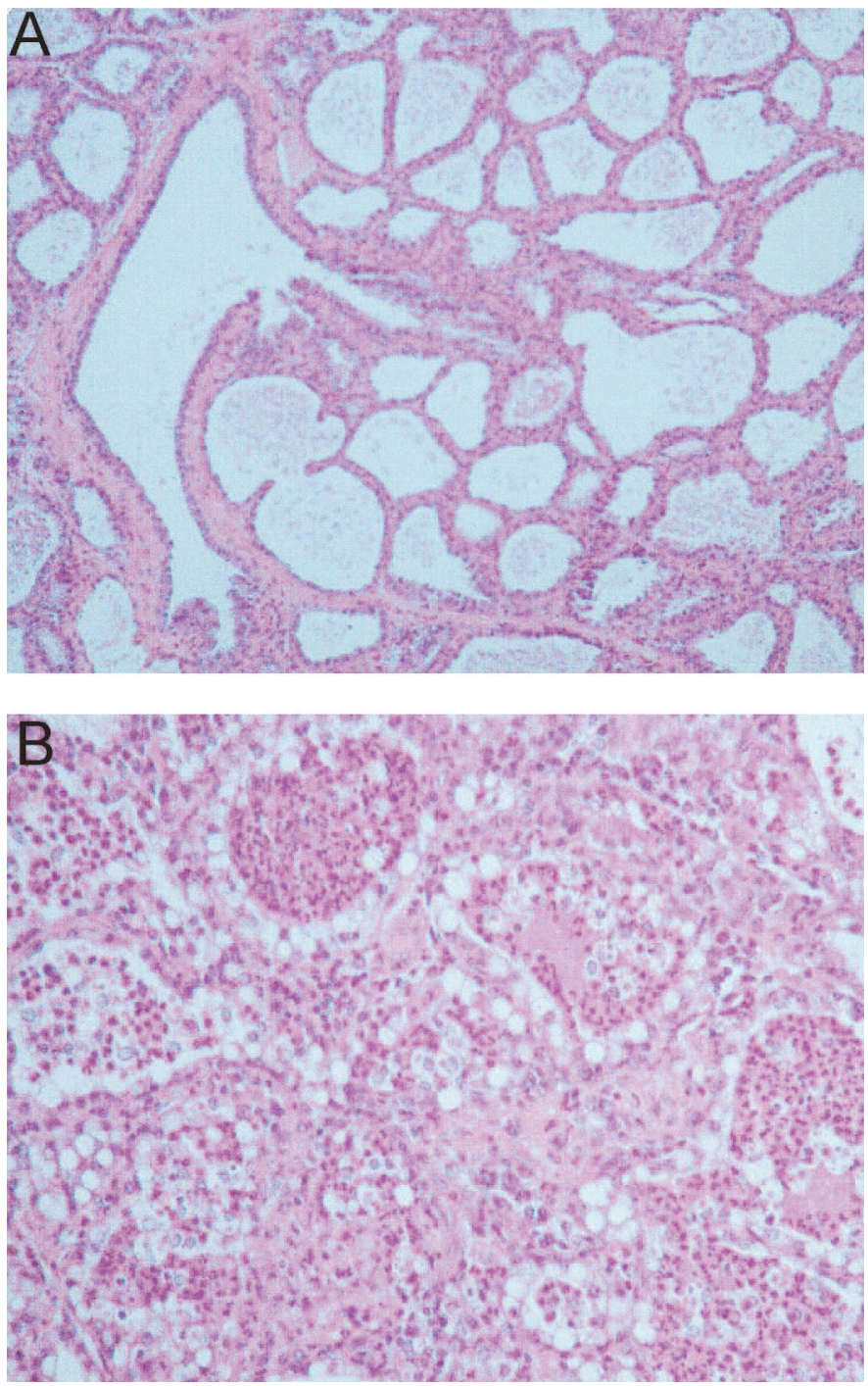

Figure 3. Micrographs of control (panel A) and infected (panel B) mammary tissue stained with hematoxylin and eosin. Color version available in the online PDF.

http://www.journalofdairyscience.org/) without pooling samples. The qPCR analysis confirmed differential expression of all genes included in the study (Figure 4). Serum amyloid A was upregulated in infected udder tissue as well. Although differences in gene expression were observed between sample locations (proximal vs. distal udder), 2-way ANOVA revealed that these differences were not statistically significant, confirming the microarray results.

\section{Mammary Epithelial Cells Involved in Innate Immunity}

To examine whether infiltrating somatic milk cells or the mammary epithelium were involved in differen- 
Table 3. List of relevant up- or downregulated genes in response to clinical Streptococcus uberis infection

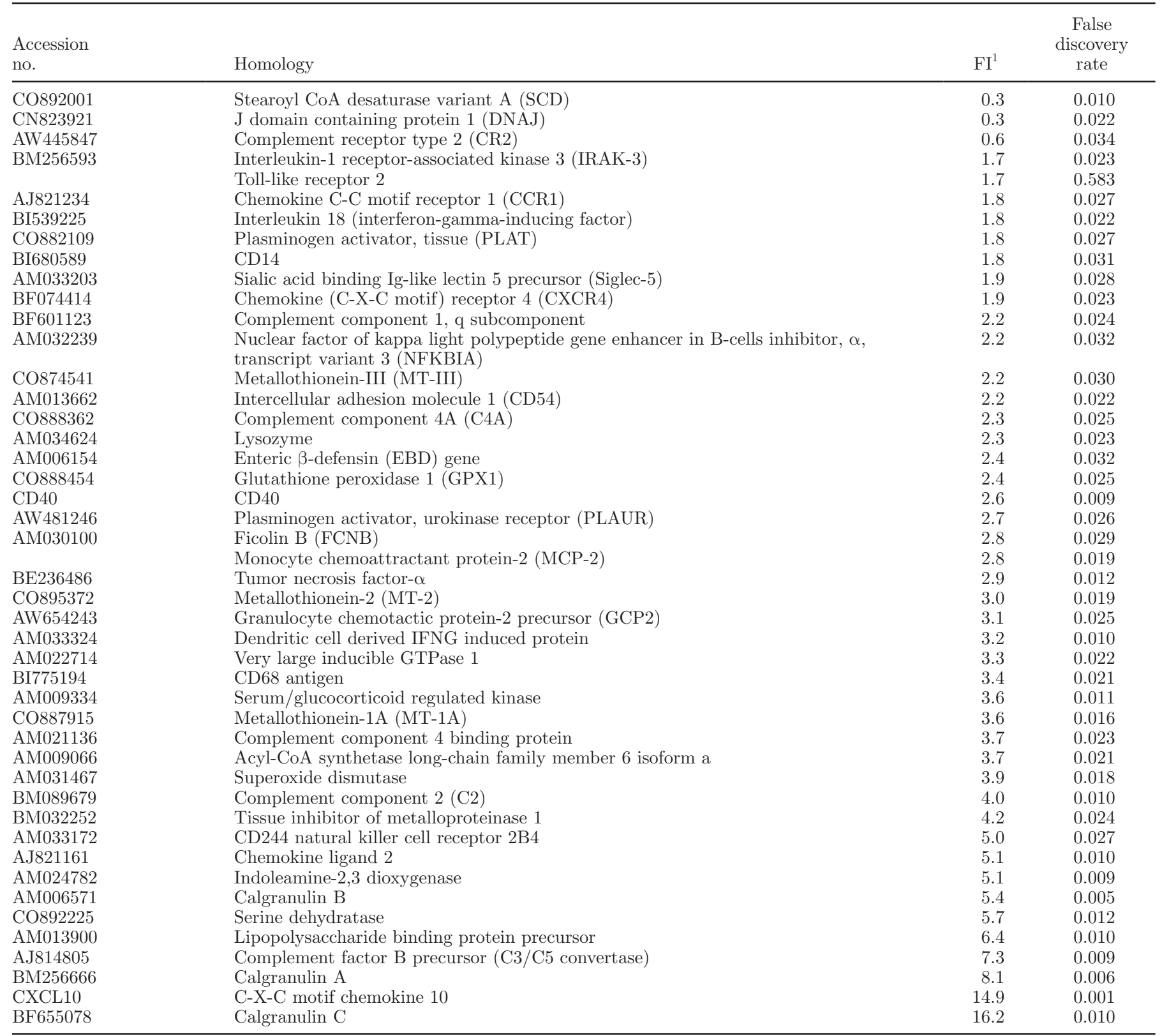

${ }^{1}$ Fold induction: infected quarters/control quarters.

tial gene expression, immunohistochemistry was used to determine the cells expressing proteins encoded by differentially expressed genes. We studied expression of 3 proteins for which gene expression was found to be induced using microarray or qPCR during Strep. uberis infection: TIMP-1, SAA, and SOD-1. Figure $5 \mathrm{~A}$ shows that although TIMP-1 protein expression was present in control mammary gland cells, expression was clearly upregulated in mammary epithelial cells from infected glands, whereas somatic milk cells showed negligible positive staining for TIMP-1. Ex- pression of SAA was induced after infection both in mammary epithelial cells and in somatic milk cells, although staining in the latter cells seemed to be less intense (Figure 5B). Basal expression of SOD-1 was present in control tissue, similar to TIMP-1 expression. However, a clear increase in protein expression of SOD-1 was observed in infected tissue, in both mammary epithelial cells and somatic milk cells (Figure $5 \mathrm{C})$. These data show that the observed differential gene expression of TIMP-1, SOD-1, and SAA was reflected by increased protein expression in mammary 


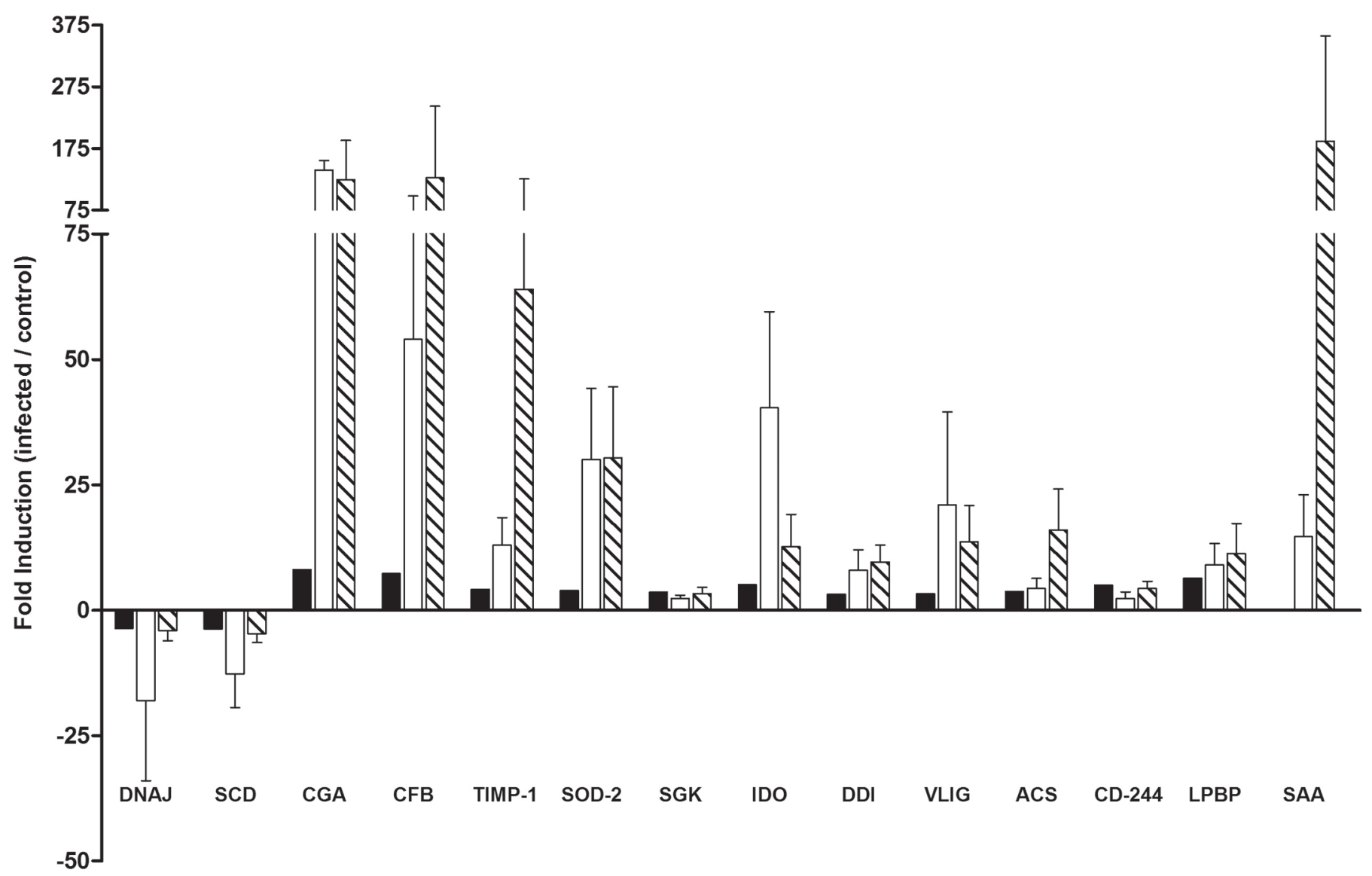

Figure 4. Confirmation of microarray results by quantitative (q)PCR analysis. Black bars indicate array results of distal and proximal mammary tissue combined, white bars indicate $\mathrm{qPCR}$ results of distal mammary tissue, and striped bars indicate $\mathrm{qPCR}$ results of proximal mammary tissue. Each bar represents the average value of 3 sample locations (quarters), and error bars indicate standard deviation. Two-way ANOVA showed no statistical difference between distal and proximal mammary tissue. SCD = stearoyl CoA desaturase; CGA = calgranulin A; $\mathrm{CFB}=$ complement factor B; TIMP-1 = tissue inhibitor of metalloproteinase 1 ; SOD-2 = superoxide dismutase 2 ; SGK = serum/glucocorticoid regulated kinase; IDO = indoleamine-2,3 dioxygenase; DDI = dendritic cell derived interferon gamma induced protein; VLIG $=$ very large inducible GTPase 1; ACS = acyl-CoA synthetase; CD-244 = cluster of differentiation 244; LPBP = LPS-binding protein; SAA = serum amyloid A.

epithelial cells (TIMP-1, SOD-1, and SAA) and in infiltrating somatic milk cells (SAA and SOD-1). This implies that the observed transcriptional changes are derived from mammary epithelial cells as well as from infiltrating cells. Together, these cell populations orchestrate the complex host response.

\section{DISCUSSION}

In this study, we used an experimentally induced Strep. uberis mastitis model to study host responses during acute infection. To ensure that animals were naïve for mastitis, primiparous heifers were used early in lactation. Animals were culled during early inflammation as determined by increased SCC and confirmed by high SAA protein concentrations in milk and plasma (Molenaar et al., 2009). In contrast to data obtained in previous studies (Leigh et al., 1990, 2010; Bannerman et al., 2004), in which animals infected with O140J showed clinical signs of disease, clinical mastitis was not observed in O140J-infected animals in this study; no clots were observed in the milk and no changes were observed in the consistency of the udder. One of the infected animals (no. 2) did not meet the criteria of culling; a small increase in SCC was observed during only one milking. Moreover, this O140J-infected animal had low milk yield at the time of infection. Intramammary challenge with Strep. uberis O140J usually leads to clinical mastitis (Leigh et al., 1990, 2010; Bannerman et al., 2004), although nonresponders have been described (Hill, 1988). The reason or mechanism behind the mild clinical outcome in animals challenged with O140J in our experiment is unknown and, because of the low number of animals, any explanation would be speculative. It could be speculated that the timing of culling after 2 successive milkings in which SCC were increased caused this mild outcome. Previously, experiments in which animals infected with O140J were followed for a 


\section{Control}
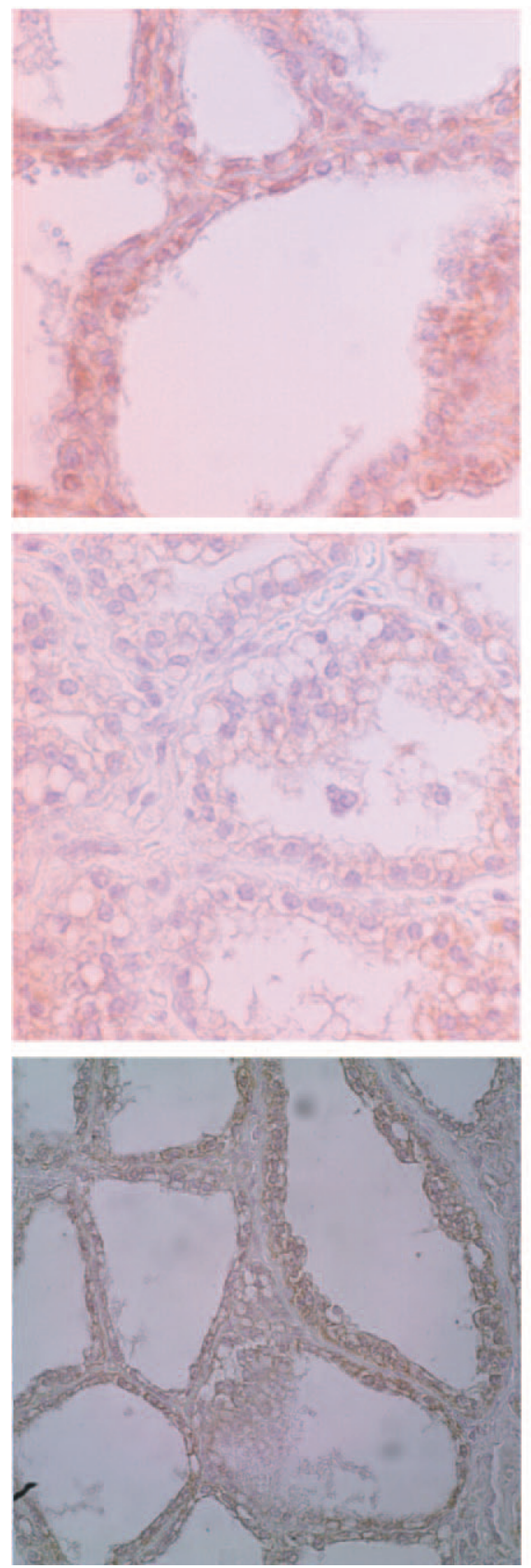

Infected

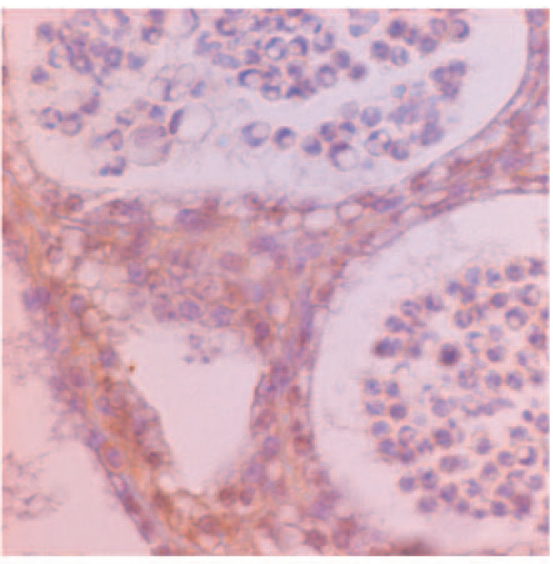

Timp-1

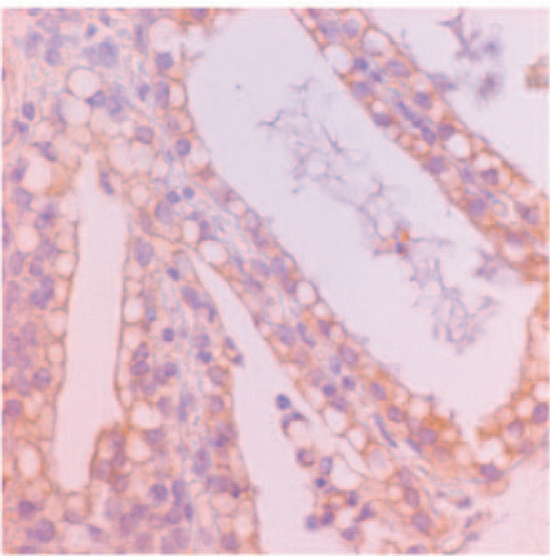

\section{SAA}

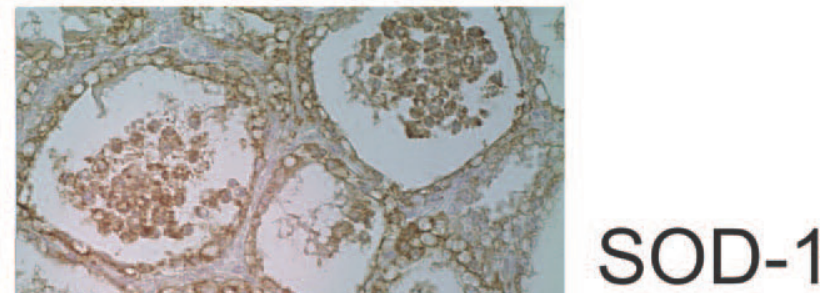

Figure 5. Immunohistochemical detection of tissue inhibitor of metalloproteinase 1 (TIMP-1), serum amyloid A (SAA), and superoxide dismutase (SOD) in mammary tissue. Control (left panel) and infected (right panel) mammary tissue was stained with antibodies against TIMP-1, SAA, and SOD-1 to localize protein expression. Color version available in the online PDF.

longer period resulted in more severe clinical outcome (data not shown).

Analysis of microarray data showed no statistically significant differences in gene expression between the different animals, challenge isolates, or sampling locations. This finding is in contrast to results reported by Rinaldi et al. (2010), who describe a time course of host responses that start in distal locations of the udder and progress to more proximal locations. Rinaldi et al. (2010) used a gram-negative pathogen rather than a gram-positive pathogen, so a different immune response would be expected (Schukken et al., 2011; Wellnitz and Bruckmaier, 2012). In addition, they killed the study animals at $24 \mathrm{~h}$ postinfection (much earlier than in our 
study), which may explain why differences between regions were obvious in their study but not in ours. Despite differences in timing of events in the $E$. coli model, similar genetic networks were affected in all regions of the mammary gland (Rinaldi et al., 2010). Likewise, Whelehan et al. (2011), who studied the transcriptome of the mammary gland $48 \mathrm{~h}$ after challenge with the gram-positive mastitis pathogen Staph. aureus, observed both differences and similarities between expression profiles of different mammary locations (Whelehan et al., 2011). Because we euthanized our animals after 2 successive increased SCC (not at a fixed time point) and subsequently selected samples with clear presence of inflammation based on histology to increase the power of analysis, we may have lost the ability to observe spatiotemporal differences. Furthermore, the relative low power of the analysis because of the small number of samples could have influenced our ability to detect such effects. Based on the similarity of microarray data across samples, as confirmed by $\mathrm{qPCR}$, microarray data from samples derived from infected quarters were combined for analysis and compared with samples derived from control quarters.

Microarray analysis revealed that expression of 239 host genes was significantly regulated in udder tissue during Strep. uberis infection. Compared with other studies, the number of regulated genes is low. Differences in the parity of animals, stages of lactation of animals, or different experimental set-up could together explain the differences in the number of differentially expressed host genes identified. Moyes et al. (2009) used multiparous cows later in lactation, whereas Swanson et al. (2009) used a noncapsular isolate at a higher challenge dose. In vitro data show that immune responses of mammary epithelial cells differ considerably between capsular and noncapsular isolates (Swanson et al., 2009), and epidemiological data suggest that differences exist in pathogenesis between capsular and noncapsular isolates (Pullinger et al., 2006; Tomita et al., 2008). Both isolates used in our study were capsular. Timing of culling of animals also differed between experiments. Furthermore, both groups used different microarrays, which could result in a different outcome.

The differentially expressed genes in our study represented several stages of the process of infection: (1) pathogen recognition; (2) chemoattraction of neutrophils; (3) tissue repair mechanisms; and (4) bactericidal activity, which are discussed below.

\section{Pathogen Recognition}

Three types of pattern recognition receptors were found to be upregulated during Strep. uberis infection: toll-like receptor (TLR) 2, LPS-binding protein
(LBP), and ficolin. Toll-like receptor 2 is a pattern recognition receptors for bacterial ligands such as lipoteichoic acid (LTA), which is present in the cell wall of Strep. uberis (Czabańska et al., 2012). Upregulation of TLR2 was previously demonstrated after induction of Strep. uberis mastitis in rats (Miao et al., 2012) and cattle (Moyes et al., 2009). Upregulation of TLR2 appears to be an evolutionarily highly conserved mechanism, as it has also been observed in fish (Basu et al., 2012). Binding of TLR2 activates nuclear factor $\kappa \mathrm{B}$ (NFkB), which subsequently leads to expression of several chemokines and cytokines. In this study, CXCL10, chemokine ligand 2, and chemokine receptors CCR1 and CXCR4 were found to be upregulated. None of these genes were found to be induced in the (Moyes et al., 2009) cattle study. Taken together, these findings suggest that TLR2 is involved in signaling during Strep. uberis infection in vivo. A second possibility, however, is that TLR2 is involved in the LBP signaling, and thus not directly upregulated because of Strep. uberis recognition but indirectly by recognition of LTA via LBP, CD14, and subsequently TLR2 (Schröder et al., 2003). In this way, LBP is involved in pattern recognition as well. Although gram-positive organisms do not contain LPS, it was recently discovered that LBP can also bind LTA, which is abundantly present in the cell wall of streptococci (Schröder et al., 2003; Mueller et al., 2006). This recognition could affect the proinflammatory response via CD14 and TLR2, which were both upregulated. Therefore, our results indicate that LBP is involved in pathogen recognition in Strep. uberis mastitis and might exert its effect via CD14 and TLR2. An increase in soluble CD14 concentration $48 \mathrm{~h}$ after intramammary challenge with Strep. uberis O140J was described by Bannerman et al. (2004).

Ficolins are receptors for pathogen-associated molecular patterns (PAMP) on bacteria that are expressed by phagocytic cells (Runza et al., 2008). The upregulation of ficolin expression probably reflects the influx of neutrophils, which are potent phagocytic cells. The ligands for ficolins are monosaccharides (Weis et al., 1992), which are abundantly present in the capsules of gram-positive bacteria. Upon binding, the complement cascade is activated (Runza et al., 2008), which was reflected in our experiment by upregulation of genes belonging to the complement system, such as complement factor $\mathrm{B}$, complement component 2, and complement component 4 binding protein. Although Swanson et al. (2009) did observe induction of 3 complement factors (C3, BF, and DAF), the induction of complement was less pronounced compared with that in our study, and the upregulation of ficolin was not observed in their study, suggesting infection had progressed to a subsequent stage in this study (Swanson et al., 2009). 


\section{Chemoattraction of Neutrophils}

During Strep. uberis infection, several chemoattractants, such as calgranulin A, B, and C, granulocyte chemotactic protein, and monocyte chemotactic protein (CCL2), were upregulated. The calgranulins were the strongest regulated genes (upregulated 6 to 16 times) in our study, whereas Swanson et al. (2009) reported only strong upregulation of calgranulin C. Upregulation of chemoattractants resulted in the observed influx of somatic cells in the udder (up to $2.9 \times 10^{7}$ cells/ $\mathrm{mL}$ ). This influx of cells was reflected by upregulation of CD markers, such as intracellular adhesion molecule 1 (ICAM-1, CD54). Expression of CD54 is known to be induced by tumor necrosis factor- $\alpha$, which was also upregulated in our experiment and in previous Strep. uberis challenge studies (Bannerman et al., 2004).

\section{Tissue Repair Mechanisms}

The influx of somatic cells, combined with the high amounts of Strep. uberis that are present in the udder, leads to tissue damage. This is reflected by the observed upregulation of the tissue-type plasminogen activator as well as urokinase-type plasminogen activator in infected tissue. Plasminogen activators convert plasminogen to plasmin, thus promoting fibrinolysis.

\section{Bactericidal Activity}

Bactericidal genes were upregulated in infected udders to kill invading pathogens, including 3 genes that encode for antioxidants: IDO, SOD, and glutathione peroxidase. Expression of these genes leads to formation of reactive oxygen species (ROS) that kill bacteria. Production of ROS by phagocytes is a key component of the antimicrobial effectiveness of the inflammatory response, but both bacteria and host cells may be affected by ROS (Erridge et al., 2008). Oxidative damage to host cells results in formation of oxidized phospholipids, including a mixture called OxPAPC (Erridge et al., 2008); OxPAPC appears to play a role in dampening down the inflammatory response through inhibition of TLR2 and TLR4 signaling. Interestingly, CD14 and LBP, both of which are found to be upregulated during Strep. uberis infection, inhibit this downregulation of the inflammatory response by OxPAPC (Erridge et al., 2008). Thus, pathogen recognition of Strep. uberis by the host, which is essential to initiation of the host immune response, may also limit the host's ability to control the damage done by the immune response. Other bactericidal genes that were upregulated during Strep. uberis infection in the current study are metallothioneins-1, 2, and 3, lysozyme, and $\beta$-defensin.
Pathogen recognition, chemoattraction, tissue repair, and bactericidal activity were found to be regulated by Strep. uberis in another study in which the Gene Ontology terms immune response, reactive oxygen, acute phase response, and immune response were overrepresented (Swanson et al., 2009). Several important genes were identified to be regulated in both studies, such as calcium binding proteins, the acute phase proteins haptoglobin and LBP, and CD14. A major difference between the latter study and ours was the small number of genes involved in cell death found in our study. Only 2 genes (IRAK, IL-1 receptor-associated kinase inhibitor of kappa-B alpha) were regulated during Strep. uberis infections, whereas Swanson et al. (2009) found 15 genes related to cell death. This suggests that, in our model, the infection had not progressed so far that cell death occurred, which could be explained by the earlier time points at which our animals were sampled ( 45 to $67 \mathrm{~h}$ in our study vs. 60 to $132 \mathrm{~h}$ in the study of Swanson et al., 2009). The effect of time postchallenge is also reflected in the fact that Swanson et al. (2009) found a downregulation of the expression of milk proteins that is not (yet) reflected in our data set. In our model, the complement and coagulation cascade was strongly affected, with 8 significantly regulated genes (c1r, c1q, SERPING, C4BP, BF, PLAT, PLAUR, and FB), whereas Swanson et al. (2009) only found 3 affected genes in this cascade. These data are in agreement with the observations that, early in $E$. coli and Staph. aureus mastitis, the complement system was also found to be regulated (Günther et al., 2009; Genini et al., 2011). In addition to time and dose effects, the difference between encapsulated and nonencapsulated Strep. uberis may be an important driver of the differences between our results and those reported by Swanson and coworkers (2009). Previously, it had been shown that the host response may differ between species with in a genus (Bonnefont et al., 2011); here, we provide preliminary evidence that the host response may differ between strains within a species.

During mastitis, high numbers of milk somatic cells invade the udder. Observed differential gene expression could, therefore, reflect a change in tissue composition during inflammation or a change in gene expression of mammary cells or a combination of the two. Using immunohistochemistry, we showed that TIMP-1 and SOD-2 protein expression was induced in mammary cells and in infiltrating somatic milk cells. Expression of SAA was exclusively induced in mammary cells surrounding the alveoli. Unfortunately, induction of SAA expression was not detected on the microarray, which probably reflects a technical issue of the microarray used. The expressed sequence tag clone representing SAA-3 did not show sequence homology to SAA in the 
database, suggesting erroneous annotation. This means that either SAA is not represented on the array or it is represented but incorrectly annotated. Bonnefont and colleagues (2011) also reported that a gene known to play an important role in intramammary inflammation was missing from their microarray analysis due to missing data.

In vitro studies demonstrated the involvement of mammary epithelium in the defense against E. coli and Staph. aureus mastitis (Schukken et al., 2011), whereas for Strep. uberis it was shown that transcriptional responses of mammary epithelium depend in part on the presence of capsular material. Based on immunohistochemistry data, we provide evidence that (signals from) mammary epithelial cells are involved in the changes of gene expression observed during early innate immune response against Strep. uberis mastitis in vivo. The infiltrating somatic milk cells were shown to be involved in observed changes in gene expression as well, because increased protein expression of both SAA and SOD was found in these cells, suggesting that they are not only effector cells attracted to clear the infection. Changes in gene expression within milk somatic cells also play a role in the orchestration of the inflammation process, as demonstrated in sheep, where differences in transcriptional responses to mastitis pathogens were found in mastitis-resistant versus mastitis-sensitive sheep (Bonnefont et al., 2011).

Based on our results, we cannot conclude whether the observed changes in gene expression are a direct effect of interaction of Strep. uberis with epithelial cells via the pattern recognition receptors, or that the influx of milk somatic cells, acute phase proteins, or other inflammatory mediators triggers this immune response in mammary cells. We showed that mammary epithelial cells and milk somatic cells change their gene and protein expression profiles in response to Strep. uberis challenge.

\section{CONCLUSIONS}

Taken together, our data show that within $48 \mathrm{~h}$ after infection with Strep. uberis, animals develop severe inflammatory responses reflected by clinical features, such as high SCC, and by changes in gene and protein expression. Intervention strategies should therefore be aimed at (very) early diagnostics to detect Strep. uberis. This study identified some genes expressed early that might be useful for early warning diagnostics. Furthermore, our data suggest that it might be helpful to combine bactericidal therapy with immunomodulatory components that target specific immune processes, such as a temporal blocking of TLR-2 signaling. In this way, a more prompt and efficient immune response could be induced to prevent (clinical) mastitis.

\section{ACKNOWLEDGMENTS}

This project was financed by FP6-EADGENE (European Animal Disease Genomics Network of Excellence).

\section{REFERENCES}

Bannerman, D. D., M. J. Paape, J. P. Goff, K. Kimura, J. D. Lippolis, and J. C. Hope. 2004. Innate immune response to intramammary infection with Serratia marcescens and Streptococcus uberis. Vet. Res. 35:681-700.

Basu, M., B. Swain, B. R. Sahoo, N. K. Maiti, and M. Samanta. 2012 Induction of toll-like receptor (TLR) 2, and MyD88-dependent TLR- signaling in response to ligand stimulation and bacterial infections in the Indian major carp, mrigal (Cirrhinus mrigala). Mol. Biol. Rep. 39:6015-6028.

Bonnefont, C. M., M. Toufeer, C. Caubet, E. Foulon, C. Tasca, M. R. Aurel, D. Bergonier, S. Boullier, C. Robert-Granie, G. Foucras, and R. Rupp. 2011. Transcriptomic analysis of milk somatic cells in mastitis resistant and susceptible sheep upon challenge with Staphylococcus epidermidis and Staphylococcus aureus. BMC Genomics 12:208.

Bradley, A. J., K. A. Leach, J. E. Breen, L. E. Green, and M. J. Green. 2007. Survey of the incidence and aetiology of mastitis on dairy farms in England and Wales. Vet. Rec. 160:253-257.

Compton, C. W., C. Heuer, K. Parker, and S. McDougall. 2007. Epidemiology of mastitis in pasture-grazed peripartum dairy heifers and its effects on productivity. J. Dairy Sci. 90:4157-4170.

Czabańska, A., O. Neiwert, B. Lindner, J. Leigh, O. Holst, and K. A. Duda. 2012. Structural analysis of the lipoteichoic acids isolated from bovine mastitis Streptococcus uberis 233, Streptococcus dysgalactiae 2023 and Streptococcus agalactiae 0250. Carbohydr. Res. 361:200-205.

Erridge, C., S. Kennedy, C. M. Spickett, and D. J. Webb. 2008. Oxidized phospholipid inhibition of toll-like receptor (TLR) signaling is restricted to TLR2 and TLR4: Roles for CD14, LPS-binding protein, and MD2 as targets for specificity of inhibition. J. Biol. Chem. 283:24748-24759.

Field, T. R., P. N. Ward, L. H. Pedersen, and J. A. Leigh. 2003. The hyaluronic acid capsule of Streptococcus uberis is not required for the development of infection and clinical mastitis. Infect. Immun. 71:132-139.

Genini, S., B. Badaoui, G. Sclep, S. C. Bishop, D. Waddington, M. H. Pinard van der Laan, C. Klopp, C. Cabau, H. M. Seyfert, W. Petzl, K. Jensen, E. J. Glass, A. de Greeff, H. E. Smith, M. A. Smits, I. Olsaker, G. M. Boman, G. Pisoni, P. Moroni, B. Castiglioni, P. Cremonesi, M. Del Corvo, E. Foulon, G. Foucras, R. Rupp, and E. Giuffra. 2011. Strengthening insights into host responses to mastitis infection in ruminants by combining heterogeneous microarray data sources. BMC Genomics 12:225.

Günther, J., D. Koczan, W. Yang, G. Nurnberg, D. Repsilber, H. J. Schuberth, Z. Park, N. Maqbool, A. Molenaar, and H. M. Seyfert. 2009. Assessment of the immune capacity of mammary epithelial cells: Comparison with mammary tissue after challenge with Escherichia coli. Vet. Res. 40:31.

Hill, A. W. 1988. Pathogenicity of two strains of Streptococcus uberis infused into lactating and non-lactating bovine mammary glands. Res. Vet. Sci. 45:400-404.

Jacobsen, S., T. A. Niewold, E. Kornalijnslijper, M. J. Toussaint, and E. Gruys. 2005. Kinetics of local and systemic isoforms of serum amyloid A in bovine mastitic milk. Vet. Immunol. Immunopathol. 104:21-31.

Jansen, J., G. van Schaik, R. J. Renes, and T. J. Lam. 2010. The effect of a national mastitis control program on the attitudes, knowl- 
edge, and behavior of farmers in the Netherlands. J. Dairy Sci. 93:5737-5747.

Jayarao, B. M., B. E. Gillespie, M. J. Lewis, H. H. Dowlen, and S. P. Oliver. 1999. Epidemiology of Streptococcus uberis intramammary infections in a dairy herd. Zentralbl. Veterinarmed. B 46:433-442.

Leigh, J. A., S. A. Egan, P. N. Ward, T. R. Field, and T. J. Coffey. 2010. Sortase anchored proteins of Streptococcus uberis play major roles in the pathogenesis of bovine mastitis in dairy cattle. Vet. Res. 41:63.

Leigh, J. A., T. R. Field, and M. R. Williams. 1990. Two strains of Streptococcus uberis, of differing ability to cause clinical mastitis, differ in their ability to resist some host defence factors. Res. Vet. Sci. $49: 85-87$.

Miao, J., J. Zhang, L. Zheng, X. Yu, W. Zhu, and S. Zou. 2012. Taurine attenuates Streptococcus uberis-induced mastitis in rats by increasing T regulatory cells. Amino Acids 42:2417-2428. http:// dx.doi.org/10.1007/s00726-011-1047-3.

Molenaar, A. J., D. P. Harris, G. H. Rajan, M. L. Pearson, M. R. Callaghan, L. Sommer, V. C. Farr, K. E. Oden, M. C. Miles, R. S. Petrova, L. L. Good, K. Singh, R. D. McLaren, C. G. Prosser, K. S. Kim, R. J. Wieliczko, M. H. Dines, K. M. Johannessen, M. R. Grigor, S. R. Davis, and K. Stelwagen. 2009. The acute-phase protein serum amyloid A3 is expressed in the bovine mammary gland and plays a role in host defence. Biomarkers 14:26-37.

Moyes, K. M., J. K. Drackley, J. L. Salak-Johnson, D. E. Morin, J. C. Hope, and J. J. Loor. 2009. Dietary-induced negative energy balance has minimal effects on innate immunity during a Streptococcus uberis mastitis challenge in dairy cows during midlactation. J. Dairy Sci. 92:4301-4316.

Mueller, M., C. Stamme, C. Draing, T. Hartung, U. Seydel, and A. B. Schromm. 2006. Cell activation of human macrophages by lipoteichoic acid is strongly attenuated by lipopolysaccharide-binding protein. J. Biol. Chem. 281:31448-31456.

Olde Riekerink, R. G., H. W. Barkema, D. F. Kelton, and D. T. Scholl. 2008. Incidence rate of clinical mastitis on Canadian dairy farms. J. Dairy Sci. 91:1366-1377.

Pullinger, G. D., M. Lopez-Benavides, T. J. Coffey, J. H. Williamson, R. T. Cursons, E. Summers, J. Lacy-Hulbert, M. C. Maiden, and J. A. Leigh. 2006. Application of Streptococcus uberis multilocus sequence typing: Analysis of the population structure detected among environmental and bovine isolates from New Zealand and the United Kingdom. Appl. Environ. Microbiol. 72:1429-1436.

Rinaldi, M., R. W. Li, D. D. Bannerman, K. M. Daniels, C. EvockClover, M. V. Silva, M. J. Paape, B. Van Ryssen, C. Burvenich, and A. V. Capuco. 2010. A sentinel function for teat tissues in dairy cows: dominant innate immune response elements define early response to $E$. coli mastitis. Funct. Integr. Genomics 10:21-38.

Runza, V. L., W. Schwaeble, and D. N. Mannel. 2008. Ficolins: Novel pattern recognition molecules of the innate immune response. Immunobiology 213:297-306.
Sampimon, O., H. W. Barkema, I. Berends, J. Sol, and T. Lam. 2009. Prevalence of intramammary infection in Dutch dairy herds. J. Dairy Res. 76:129-136.

Schröder, N. W., S. Morath, C. Alexander, L. Hamann, T. Hartung, U. Zahringer, U. B. Gobel, J. R. Weber, and R. R. Schumann. 2003. Lipoteichoic acid (LTA) of Streptococcus pneumoniae and Staphylococcus aureus activates immune cells via Toll-like receptor (TLR)-2, lipopolysaccharide-binding protein (LBP), and CD14, whereas TLR-4 and MD-2 are not involved. J. Biol. Chem. 278:15587-15594

Schukken, Y. H., J. Gunther, J. Fitzpatrick, M. C. Fontaine, L. Goetze, O. Holst, J. Leigh, W. Petzl, H. J. Schuberth, A. Sipka, D. G. Smith, R. Quesnell, J. Watts, R. Yancey, H. Zerbe, A. Gurjar, R. N. Zadoks, and H. M. Seyfert., and members of the Pfizer mastitis research consortium. 2011. Host-response patterns of intramammary infections in dairy cows. Vet. Immunol. Immunopathol. 144:270-289.

Smith, K. L., and J. S. Hogan. 1993. Environmental mastitis. Vet. Clin. North Am. Food Anim. Pract. 9:489-498.

Swanson, K. M., K. Stelwagen, J. Dobson, H. V. Henderson, S. R. Davis, V. C. Farr, and K. Singh. 2009. Transcriptome profiling of Streptococcus uberis-induced mastitis reveals fundamental differences between immune gene expression in the mammary gland and in a primary cell culture model. J. Dairy Sci. 92:117-129.

Tomita, T., B. Meehan, N. Wongkattiya, J. Malmo, G. Pullinger, J. Leigh, and M. Deighton. 2008. Identification of Streptococcus uberis multilocus sequence types highly associated with mastitis. Appl. Environ. Microbiol. 74:114-124.

Weis, W. I., K. Drickamer, and W. A. Hendrickson. 1992. Structure of a C-type mannose-binding protein complexed with an oligosaccharide. Nature 360:127-134.

Wellnitz, O., and R. M. Bruckmaier. 2012. The innate immune response of the bovine mammary gland to bacterial infection. Vet. J. $192: 148-152$.

Whelehan, C. J., K. G. Meade, P. D. Eckersall, F. J. Young, and C. O'Farrelly. 2011. Experimental Staphylococcus aureus infection of the mammary gland induces region-specific changes in innate immune gene expression. Vet. Immunol. Immunopathol. 140:181189.

Zadoks, R. N., H. G. Allore, H. W. Barkema, O. C. Sampimon, Y. T. Grohn, and Y. H. Schukken. 2001. Analysis of an outbreak of Streptococcus uberis mastitis. J. Dairy Sci. 84:590-599.

Zadoks, R. N., B. E. Gillespie, H. W. Barkema, O. C. Sampimon, S. P. Oliver, and Y. H. Schukken. 2003. Clinical, epidemiological and molecular characteristics of Streptococcus uberis infections in dairy herds. Epidemiol. Infect. 130:335-349.

Zadoks, R. N., J. R. Middleton, S. McDougall, J. Katholm, and Y. H. Schukken. 2011. Molecular epidemiology of mastitis pathogens of dairy cattle and comparative relevance to humans. J. Mammary Gland Biol. Neoplasia 16:357-372. 